\title{
Study of Microbial Pollution in River Beehar Water District Rewa Madhya Pradesh, India
}

\author{
Kiran Singh* ${ }^{1}$, Skand Mishra ${ }^{1}$, Sangam Lal Dwivedi ${ }^{2}$ and Ravi Kumar Mishra ${ }^{3}$ \\ ${ }^{I}$ Govt. TRS Darbar College Rewa. M.P. \\ ${ }^{2}$ M.G.C.G.V. Chitrakoot Satna, Madhya Pradesh \\ ${ }^{3}$ SRK University Bhopal, Madhya Pradesh
}

\begin{abstract}
Water is one of the best gifts to all living creature, given by nature. It is compulsory for the growth and maintenance of human body and also for many biological activities. It plays a vital role for the survival of all forms of life of earth and works as a universal solvent. Pollution is caused when a change in the physical, chemical or biological condition in the environment harmfully affect quality of human life including other animal's life and plant The quality of water is typically determined by monitoring microbial presence, especially total coliforms, fecal coliforms and fecal streptococci. The total coliform count varied in the range of 836-1987.43 MPN/100 ml, 743-981 MPN/100ml, 1115.4 to $2010 \mathrm{MPN} / 100 \mathrm{ml}$; fecal coliform varied in the range of 763-1947.61 MPN/100 ml, 547-979 MPN/100 ml and 1057 to $1378 \mathrm{MPN} / 100 \mathrm{ml}$ and fecal streptococci varied in the range of 881-1969.53 and 832.63-1098.86 MPN/100 ml, 1155 to $1512 \mathrm{MPN} / 100 \mathrm{ml}$ during winter, summer and rainy season, respectively.
\end{abstract}

Keywords: Microbial, pollution, coliforms, environment, water quality.

\section{INTRODUCTION}

River Beehar is a source of fresh water for Rewa district. The total length of the river is about $84.3 \mathrm{~km}$ and flows from Pratapgarh Amarpatan in Satna district to Tamra, Ghoghar, Amriti, Ravsar, Bansghat, Kitwariya, Vikramghat, Karahiya and Chachai villeges of rewa district.

Trivedi And Kataria[1] in 2012 through their study stated that Fresh Water is essential to existence of life. Water of acceptable quality is essential not only for drinking and domestic purposes but also for agriculture, industrial and commercial uses. Surface water is collection of water on the ground or in a stream, river, lake, wetland, or ocean. Surface water is naturally replenished by precipitation and naturally lost through discharge to evaporation and sub-surface seepage into the groundwater. A lake is a large body of water surrounded by land and inhabited by various aquatic life forms. Lakes are subjected to various natural processes taking place in the environment, such as the hydrological cycle. Due to tremendous population growth of the city (from just over 0.1 million in 1951 to about 1.8 millions in 2000) and rapid urban development, lakes are facing various environmental problems resulting in deterioration of its $\mathrm{w}$ wasteful water consumption and improper waste disposal practices have led to deterioration in the water quality be it surface or ground water.

Pollution is caused when a change in the physical, chemical or biological con Uncontrolled domestic wastewater discharge into pond as resulted in eutrophication of ponds as evidence by substantial algal bloom, dissolve oxygen depletion in the subsurface water leads to large fish kill and other oxygen requiring organism[2]. Effluent is discharge into environment with enhanced concentration of nutrient, sediment and toxic substances may have a serious negative impact on the quality and life forms of the receiving water condition in the environment harmfully affect quality of human life including other animal's life and plant[3,4]. Industrial, sewage, municipal wastes are been continuously added to water bodies hence affect the physiochemical quality of water making them unfit for use of livestock and other organisms [5].water quality.

Indiscriminate and body when discharge untreated or partially treated ${ }^{5}$. Water pollution by effluent has become a question of considerable public and scientific concern in the light of evidence of their extreme toxicity to human health and to biological ecosystems[6-7]. Rivers have always been the most important resource of fresh water. India support more than $16 \%$ of the world population with only $4 \%$ of the world's fresh water resources[8]. India is a land of many rivers. The total length of all our major rivers together with their tributaries is $27,359 \mathrm{~km}$. Many of our ancient civilizations had flourished along the banks of some river and even now most developmental activities are dependent upon them[9]. Anthropogenic interruptions of the land surface, modifications of the river system and increasing rates of water consumption are negatively 
impacting the quality of fresh water sources throughout the world[10]. In international treaties, the need for water quality reflects the deep impact of economic, technological and demographic changes upon the water environments. Since the modern agricultural, industrial and chemical revolutions, the explosion of the world's population and spread of the urbanization were introduced as the factors affecting water quality in both domestic and international policies[11]. Spatial and temporal variations in river hydrochemistry have a strong effect on the concentration of pollutants in water one of the most important factors of water pollution is the microbial contamination; especially with pathogenic microorganisms due to fecal discharges[12]. This problem is further compounded by the increasing incidence of enteric pathogens in fresh water system [13-16] which are responsible for waterborne diseases[17,18] such as cholera, shigellosis, salmonellosis, pneumonia and typhoid fever[19,20]. These diseases are one of the major causes of increased morbidity and mortality in the world. According to the World Health Organization (2006) [21], one third of the world population suffers from diseases derived from contaminated unsafe water supply and about 13 million people die every year from waterborne infections; of these, 2 million are children. The majority of these deaths occur in developing countries. Unsafe water with inadequate sanitation and insufficient hygiene accounts for an estimated $1.9 \%$ global burden of disease and 6.3 percent of all deaths (WHO, 2006). Among these 1.7 million deaths in a year globally is mainly through infectious diarrhea[22-24]. The Beehar river an important surface water source of Rewa town, is a tributary of the Tons river. It originates from the Vindhyan hill range near Amarpatan in the Satna district of Madhya Pradesh. It flows northerly and makes the confluence study with the Tons near Chachal village in the Rewa district. The study area is located between latitude $24^{\circ} 25^{\prime}$ : $25^{\circ} 00^{\prime}$ and longitude $81^{\circ} 30^{\prime}$. The average rainfall of the area is about $1000 \mathrm{~mm}$ whereas temperature varies between $4^{\circ} \mathrm{C}$ in winter to $42^{\circ} \mathrm{C}$ in summer season.

The growing problem of deterioration of water quality along stretch of river Beehar requires regular monitoring. Study of the bacteriological study provides the actual pollution state of river water.

\section{MATERIAL AND METHODS}

Samplings were conducted during $1^{\text {st }}$ Oct 2013 to $15^{\text {th }}$ June 2014 , at nine different stations viz. Kitwarya, Ghoghar, Ravsar, Bansghat, Amriti, Karahiya, Chachai, Vikramghat and Tamra of river Beehar during the winter, and summer seasons.
Water samples were collected from the surface and subsurface layers (30 $\mathrm{cm}$ below the surface) from each site and brought to the laboratory under icecold condition for bacteriological analysis. All the samples were refrigerated at $4^{0} \mathrm{C}$ in the laboratory [12-15], and procedures were followed as per the standard methods[25].

\section{SAMPLE COLLECTION}

From $1^{\text {st }}$ Oct 2013 to $15^{\text {th }}$ June 2014,18 water samples $(2000 \mathrm{ml} /$ sampling site $)$ were collected in presterilized bottles from the surface and $1.5 \mathrm{ft}$ below the surface from all the sampling sites of river Beehar on seasonal basis i.e. during winter and summer seasons. Samples were brought to the laboratory under ice-cold conditions and processed immediately.

\section{RESULTS AND DISCUSSION}

The microbial population in a natural water body, to a large extent, is governed by its physical and chemical condition, which prevails in that habitat. In developing and underdeveloped countries with inadequate sanitation, fecal contamination of fresh water by enteric pathogens is very common or widespread, as a consequence plethora of enteric pathogen in a fresh water system play a vital role in causing pathogenic diseases in humans and bovines

\section{FECAL COLIFORMS (FC)}

The seasonal variation in Fecal Coliforms (FC) (mean) at different ghats of river Beeher during the study period is presented in fig. $1 p$. It ranged from 763 to $1245 \mathrm{MPN} / 100 \mathrm{ml}$ Kitwariya, 739.6 to $1257 \mathrm{MPN} / 100 \mathrm{ml}$ at Ghoghar, 547 to 1278 MPN/100ml at Ravsar, 896.63 to $1057 \mathrm{MPN} / 100 \mathrm{ml}$ at Bansghat, 976.79 to $1256 \mathrm{MPN} / 100 \mathrm{ml}$ at Amriti, 901.36 to $1245.69 \mathrm{MPN} / 100 \mathrm{ml}$ at Karahiya 879.36 to $1354 \mathrm{MPN} / 100 \mathrm{ml}$ at Chachai, 763.71 to 1165 MPN/100 $\mathrm{ml}$ at Vikramghat, 937.71 to 1947.61 MPN/100 ml at Tamra.

Fecal coliforms were found in the range of 763 to $1947.61 \mathrm{MPN} / 100 \mathrm{ml}, 547-979 \mathrm{MPN} / 100 \mathrm{ml}$ and 1057 to $1378 \mathrm{MPN} / 100 \mathrm{ml}$ during winter, summer and rainy season, respectively.

In Tamra, maximum value of fecal coliform (1947.61 MPN/100 ml) was recorded whereas minimum value of the fecal coliform (547 MPN/100 $\mathrm{ml}$ ) was recorded at Ravsar during summer season.

\section{FECAL STREPTOCOCCI (FS)}

The seasonal variation in Fecal Streptococci (FS) (mean) in river Beehar at different ghats during the study period is presented in fig. 1q. It ranged from 942 to 1155 MPN/100 Kitwariya, 937 to $1863.6 \mathrm{MPN} / 100 \mathrm{ml}$ at Ghoghar, 869 to 1256 MPN/100 ml at Ravsar, 936.48 to $1256 \mathrm{MPN} / 100 \mathrm{ml}$ 
at Bansghat, 889 to $1478 \mathrm{MPN} / 100 \mathrm{ml}$ at Amriti, 953 to $1512 \mathrm{MPN} / 100 \mathrm{ml}$ at Karahiya, 881 to 1278 MPN/100 $\mathrm{ml}$ at Chachai, 832.63 to $1211 \mathrm{MPN} / 100$ $\mathrm{ml}$ at Vikramghat and 973.69 to 1969.53 MPN/100ml at Tamra Fecal streptococci ranged from 881 to $1969.53 \mathrm{MPN} / 100 \mathrm{ml}, 832.63$ to 1098.86 MPN/100 ml and 1155 to $1512 \mathrm{MPN} / 100$ $\mathrm{ml}$ during winter, summer and rainy season, respectively.

In Tamra, maximum value of Fecal Streptococci (1969.53 MPN/100 ml) was recorded during winter season whereas minimum value of the Fecal Streptococci was recorded at Vikramghat (832.63 MPN/100 ml) during summer season.

\section{HETEROTROPHIC PLATE COUNT (HPC)}

The seasonal variation in heterotrophic plate count (mean) at different ghats of river Beehar during the study period is presented in fig. $1 \mathrm{r}$. It ranged from 16.93 to $63.77 \times 10^{2} \mathrm{CFU} / \mathrm{ml}$ at Kitwariya, 36.73 to $69.77 \times 10^{2} \mathrm{CFU} / \mathrm{ml}$ at Ghoghar, 15.52 to $84.39 \times 10^{2} \mathrm{CFU} / \mathrm{ml}$ at Ravsar, 17.68 to $69.99 \times 10^{2} \mathrm{CFU} / \mathrm{ml}$ at Bansghat, 49.17 to $69.77 \times$ $10^{2} \mathrm{CFU} / \mathrm{ml}$ at Amriti, 31.14 to $63.16 \times 10^{2} \mathrm{CFU} / \mathrm{ml}$ at Karahiya, 40.16 to $57.44 \times 10^{2} \mathrm{CFU} / \mathrm{ml}$ at Chachai, 46.66 to $67.15 \times 10^{2} \mathrm{CFU} / \mathrm{ml}$ at Vikramghat, 33.78 to $54.42 \times 10^{2} \mathrm{CFU} / \mathrm{ml}$ at Tamra.

During the present study, total coliforms were observed in the range of 836-1987.43 MPN/100 ml during winter season, 743-981 MPN/100 ml during summer season and 1115.4 $2010 \mathrm{MPN} / 100 \mathrm{ml}$ during the rainy season. However fecal coliforms were found in the range of 763 to 1947.61 MPN/100 ml, 547-979 MPN/100 ml and 1057-1378 MPN/100 ml during winter, summer and rainy seasons, respectively. High density of total coliforms in most of the stations may be due to direct interaction of Beehar catchment areas with human activities. People use the Beehar water for various recreational activities viz. swimming, bathing etc. while according to DWAF (1996)[26], the range of coliform $>2000 \mathrm{MPN} / 100 \mathrm{ml}$ increases the risk of contracting gastrointestinal illness among water user. During the present study the coliform count was found very much higher than the prescribed limit [100 MPN/100 ml (WHO, 2006)] indicated that water is not potable for drinking and other recreational purposes. As a consequence, coliforms detected in higher concentrations than pathogenic bacteria, are used as an index of the potential presence of enteropathogens in water environments[27,28]. Currently, coliforms and $E$. coli are of great importance among bacterial indicators used in water quality definition and health risk [28-29]. The greater the fecal coliform count, the greater the probability of contracting diseases from waterborne pathogenic bacteria [30-32].

\section{CONCLUSION}

The quality of water is typically determined by monitoring microbial presence, especially total coliforms, fecal coliforms and fecal streptococci. The total coliform count varied in the range of 8361987.43 MPN/100 ml, 743-981 MPN/100ml, 1115.4 to $2010 \mathrm{MPN} / 100 \mathrm{ml}$; fecal coliform varied in the range of 763-1947.61 MPN/100 ml, 547-979 MPN/100 ml and 1057 to $1378 \mathrm{MPN} / 100 \mathrm{ml}$ and fecal streptococci varied in the range of 881-1969.53 and 832.63-1098.86 MPN/100 ml, 1155 to 1512 MPN/100 ml during winter, summer and rainy season, respectively. Analysis of heterotrophic bacterial count in an aquatic system is of primary importance for evaluating its trophic status as well as for assessing the input of microorganisms in aquatic environment. The heterotrophic bacterial count in river Beehar varied from of $16.93 \times 10^{2}-84.39 \times 10^{2}$ $(\mathrm{CFU} / \mathrm{ml}), 15.52 \times 10^{2}-53.63 \times 10^{2}(\mathrm{CFU} / \mathrm{ml})$ and $46.66 \times 10^{2}-69.99 \times 10^{2}$ during winter, summer and rainy season, respectively.

The bacteriological parameters investigated during the present course of study indicated that the pollution level has reached to its soar. Results indicated that water is not potable for drinking and other recreational purposes.

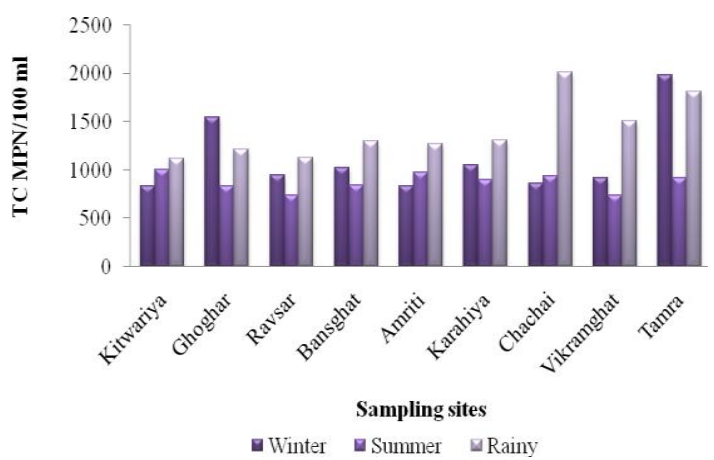

Fig. 1: Seasonal variations in physicochemical and bacteriological of Total Coliform (TC)] of river Beehar

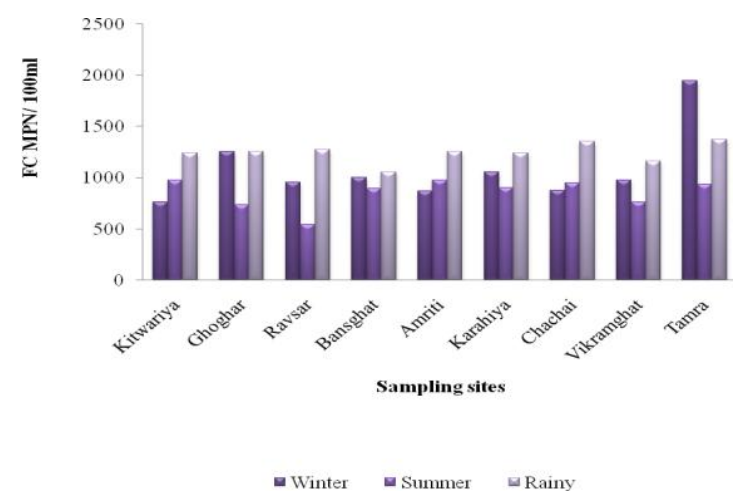




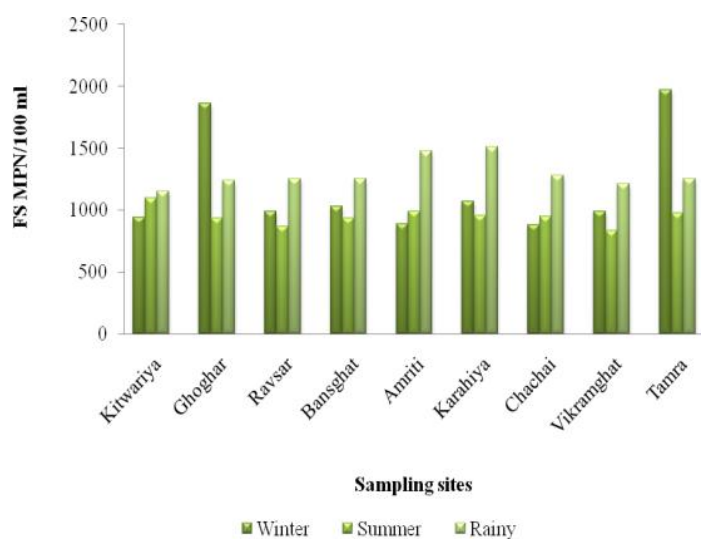

[11]. D. F. Shmueli, Political Geography, 1999, 18, 437-476.

[12]. K.Bhanja Mohanta, A.K. Patra,. Poll. Res. 2000 19(3), 377-385.

[13]. M.C. Arthur, J. V. and R. C. Tuckfield, Appl. Environ. Microbiol, 2000, 66(9), 3722-3726.

[14]. S. Jain, P. Agarwal, V. Singh Water Sci. Technol. Lib,2007,57(3),513-559.

[15]. N. J. Ashbolt, Toxicology ,2004,198, 229238.

[16]. A. Sharma ,N . Dubey, B. Sharama, Inter. J. Hyg. Environ. Health ,2005,208, 425433.

[17]. I. Karaboze, , F.Ucar, R.Eltem, , G. Ozdmir, and M. Ates, JES. , 2003, 26,118.

[18]. J .Briggs, H .Chung, M .Caffrey. J. Phys. II France 1996, 6, 723-

[19]. D.T. Goska, D. Wojnicz, Adv. Clin. Exp. Med. 2011, 20(2), 131-136.

[20]. World Health Organization (WHO) (2006) Guidelines for drinking-water quality (electronic resource). Incorporating first addendum $-3^{\text {rd }}$ ed Volume 1. Recommendations. World Health Organization, Geneva.

Fig. 2 (a-c): Seasonal variations in bacteriological characteristics [a-Fecal Coliform (FC), b-Fecal

Streptococci, c-Heterotrophic Plate Count (HPC)] of river Beehar

\section{REFERENCES}

[1]. S. Trivedi, C.H. Kataria, Current World Environment 2012 ,7(1),139-144.

[2]. G.C. Pandey, Hydrol. Proc. 2003, 10(2), 131-295.

[3]. Lowel, F Thompson, Microbiol. Mol. Biol. Rev. 1992, 68, 403-431.

[4]. P.A.C Okoye, R.E. Enemuoh, J.C. Ogunjiofor,$J$ Chem Soc Nigeria 2002,27(1), 76-77.

[5]. B.K Dwivedi, G.C. Pandey, India Poll.Res. 2002, 21(3), 361-370.

[6]. G Forenshell (2001). WRAC106.USA,2001,6.

[7]. A. Katsuro , K .Yashiko, S .Yoshinnori, T .Takashi, .S.Hayao, Analytical science 2004,20, 79-84.

[8]. K. P.Singh, A. Malik and V. K. Singh, (2003). Water Air and Soil Pollution, 2003, 170, 383-404.

[9]. S. Gholami, S. Srikantaswamy. Nat. Resour. Res. 2009, 18(3), 235-247.

[10]. M.N. Gazzaz, K.M. Yusoff, M.F. Ramli, A.Z .Aris, H.A. Juahir, Marine pollution protection 2012,64,688-698.

[21]. G. agosta, C. Evensen, E.R. Atwill, M.Walker, T. Ticktin, A .Asquith, W. Kenneth, W .Tate. Ecohealth. 2010, 7(1), 105-113.

[22]. A .Sharma, A. Bhattacharya, Bora C R, Shukla V, Parihar P (2012) Diversity of Enteropathogens in River Narmada and their Environmental and Health implications. Microorganism in Environmental Management: Microbes and Environment. Chapter 2: 35-60. Springer Science + Business Media B.V.

[23]. American Public Health Association (APHA) (1998) Standard methods for examination of water and wastewater $\left(20^{\text {th }}\right.$ ed.) Washington, DC.

[24]. Department of Water Affairs, Forestry (DWAF) (1996) South African water Quality Guidelines, Domestic Water Use ( $2^{\text {nd }}$ ed.) Pretoria 1.

[25]. A .Rompre, P .Servais, J .Baudart, M. deRoubin, P .Laurent,J. Microbiol. Meth 2002,49,31-54.

[26]. E.B.Essien, AC Olisah (2010) Nigeria. J. Pharm. Res. 3(8): 1844-1847.

[27]. N.Giannoulis, , V .Maipa, I. Konstantinou, T.Albanis, I. Dimoliatis Chemosphere 2005,58, 1269-1276.

[28]. S.Z. Sabae, S.A. Rabeh Egyptian J. Aqua. Res. 2007 33(1), 301-311. 
[29]. D. Schwartz Citrobacter infection. In: Pathology of infectious diseases, $1^{\text {st }}$ ed. Conn DH, China. Water Sci. Technol, 1997 40: $35-43$.

[30]. B.M.West, P.Liggit, D.L. Clemans, S.N. Francoeur, Water Air. Soil. Pollut. 1997, 217, 473-489.

[31]. Nishtha Koul, R.S. Lokhande and J.K. Dhar, Journal of applicable chemistry, 2012, 1(4), 512-518.

[32]. Deepak Sinha, Journal of applicable chemistry, 2013, 2(5), 1034-1048. 